\title{
TONIC PUPILS WITH ABSENT TENDON REFLEXES IN MOTHER AND DAUGHTER
}

\author{
By \\ G. DE M. RUDOLF, Bristol
}

Numerous cases have now been recorded of the above condition, but the following are described as being unusual in that $(a)$ the abnormalities occur in two relatives-mother and daughter; $(b)$ the abnormality of the pupils commenced at approximately the same age in both cases, and as regards the pupil there has been no change in one case for 32 years.

Case I. Married woman, age 61 years. The left pupil was first noticed to be small and fixed following an attack of acute and severe tonsillitis at the age of 29 years. Neither the grandparents, the parents, the husband nor seven siblings have shown inequality of the pupils.

At the age of 36 years, the patient was examined by Dr. R. J. Coulter, of Newport, Monmouthshire, who kindly informs me that he found that the left pupil was quite inactive to accommodation or direct light, but showed a very doubtful consensual reaction.

Upon examination 25 years later, at the age of 61 years, the left pupil showed no reaction to light, either directly or consensually. The reaction to accommodation was doubtful. Slight irregularity was present. The right pupil reacted normally, including consensually. Discs were clear with marked physiological cups, although the edges were somewhat illdefined all round. Visual fields were normal. Ocular movements were good and movements of face, tongue and palate were normal.

Biceps, triceps and supinator reflexes were present and equal upon the two sides but the left kneejerk and both anklejerks were absent. The right kneejerk was obtained on reinforcement only. There were no subjective symptoms in the eye or the legs.

Case II. Married woman, daughter of above, age 37 years. At the age of 33 years, following an attack of acute pyelitis, the pupils were found to be unequal.

Upon examination four years later, at the age of 37 years, the left pupil was smaller than the right and slightly irregular. There was no reaction to accommodation and none to direct light. A slight consensual reaction of a slow type was present. The right pupil reacted well, including consensually. Dises were clear with wellmarked physiological cups, but with slight indistinctness of edges. Ocular, facial, tongue and palate movements were normal. Biceps, triceps, and supinator reflexes were not obtained. The left kneejerk was absent. The right kneejerk was also absent, but paresis from acute anterior poliomyelitis had occurred in this leg at the age of 12 years.

\section{SUMMARY}

1. Two cases of tonic pupils are described occurring in the left pupils of mother and daughter. 
2. The inequality of the pupils was first noticed in the mother at the age of 29 years and in the daughter at the age of 33 years.

3. The inequality of the pupil in the mother has been present for 32 years.

\section{REFERENCES}

AdIe, W. J., Brit. Med. Jour., 1931, 1, 928.

Adie, W. J., Brit. Med. Jour., 1931, 2, 136.

ADIE, W. J., Brit. Jour. Ophthal., 1932, 16, 449.

ADIE, W. J., Brain, 1932, 55, 98.

Axenfeld, Kl. Monats. f. Augenh., 1919, 62, 59.

ВаCH, Pupillenlehre, 1917.

Barré, J. A., and Helle, Rev. neurol., 1934, 1, 542.

BARRÉ, J. A., and Klein, M., Rev. neurol., 1934, 1, 590.

BeHR, Kl. Monats. f. Augenh., 1921, 66, 770.

BeHR, Die Lehre von den Pupillenbewegungen, 1924.

Best, F., Handb. d. Ophthalmol., 1931, 6, 476.

Bing and Franceschetti, in Schieck and Brückner, Handb. d. Ophthalmol., 1931, 6, 80.

Bing, R., Gehirn und Auge, 1923.

Brain, W. R., Diseases of the Nervous System, 1933, 76.

Bumke, Die Pupillenstörungen bei Geistes- und Nervenkrankheiten, 1911.

Busscher, J. DE, Jour. belge de neurol. et de psychiat., 1935, 35, 331.

83, 203.

Gaudissart and Massion-Verniory, Jour. belge de neurol. et de psychiat., 1933,

Gehrcke, Neurol. Centralb., 1921, 40, 93.

Guillain, G., and Sigwald, J., Bull. et mém. Soc. méd. hôp. Paris, 1932, 48, 720.

Holmes, G., Trans. Ophthalmol. Soc., 1931, 51, 209.

Jelliffe, S. E., Trans. Amer. Neurol. Assoc., 1915.

JeLliffe, S. E., N.Y. Med. Jour., 1921, 113, 383.

Jelliffe, S. E., Jour. Neurol. and Psychopath., 1933, 13, 349.

Jennings, L. M., Roy. Berks. Hosp. Rep., 1933, 27.

Jess, Kl. Monats. f. Augenh., 1920, 64, 114.

Kyrieleis, W., Zeits. f. Augenh., 1934, 83, 278.

Kyrieleis, W., Münch. med. Woch., 1935, 82, 1067.

Lersperger, Kl. Monats. $f$. Augenh., 1914, 53, 241.

Markus, C., Trans. Ophthalmol. Soc., 1906, 26, 50.

MARKUS, C., Brain, 1906, 29, 293.

Moore, R. F., Trans. Ophthalmol. Soc., 1924, 44, 38.

Moone, R. F., Trans. Ophthalmol. Soc., 1931, 51, 203.

Morgan, G., and Symonds, C. P., Guy's Hosp. Rep., 1927, '77, 13.

Morgan, G., and Symonds, C. P., Proc. Roy. Soc. Med., 1931, 24, 867.

Nonne, Neurol. Centralb., 1902, 21, 1000.

Olofy, Kl. Monats. f. Augenh., 1914, 53, 493.

Schneider, M., Med. Jour. Australia, 1933, 1, 154.

Weber, F. P., Proc. Roy. Soc. Med., 1933, 26, 530.

WeILl and Reys, Rev. d'Oto.-Neuro.-Oftalm., 1926, 4, 433.

Wilbrand and Saenger, Neurol. des Auges, 1922, 9, 143.

Wilson, S. A. K., Jour. Neurol. and Psychopath., 1921, $2,1$. 